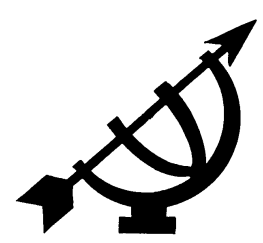

\title{
'n Leerderperspektief op dissipline: 'n kwalitatiewe ontleding
}

\author{
C.C. Wolhuter \& I.J. Oosthuizen
}

Fakulteit Opvoedingswetenskappe

Potchefstroomse Universiteit vir $\mathrm{CHO}$

POTCHEFSTROOM

E-pos: sooccw@puknet.puk.ac.za

sooijo@puknet.puk.ac.za

\section{Abstract}

A learner perspective on discipline: A qualitative analysis

Recent research has indicated that learner discipline constitutes a problem in South African schools. The aim of this research was to construct a learner perspective on discipline from a reformational point of view. A further aim was to report on an empirical study about how learners judged the state of discipline in their schools from this perspective. As part of a research project on learner discipline at the Potchefstroom University for CHE, learners at Afrikaans primary schools in the North West Province took part in an essay competition. The topic of the essay was "Discipline at my school". The essays were subjected to a content-analysis.

Learners realise the need for discipline and justify their belief in the need for discipline on practical (prerequisite for learning) and religious grounds. Most learners are of the opinion that the state of learner discipline in their schools is good. Misbehaviour that does occur is of a less serious nature (i.e. not criminal misbehaviour). Learners regard parental guiding as the most significant cause of ill-discipline at schools. A significant number of learners wrote that existing measures to maintain discipline at their schools were ineffective. Re-resorting to corporal punishment was the most commonly recommended alternative.

This article concludes with recommendations for follow-up research and improvement of education practice. 
Opsomming

'n Leerderperspektief op dissipline: 'n kwalitatiewe ontleding

Onlangse navorsing het getoon dat leerderdissipline 'n probleem in Suid-Afrikaanse skole is. Die doel van die navorsing wat hierdie artikel ten grondslag lê, was om 'n leerderperspektief op dissipline vanuit 'n reformatoriese perspektief te konstrueer. 'n Verdere doelwit was om vanuit hierdie perspektief verslag te doen oor 'n studie van hoe leerders die stand van dissipline in hul skole beoordeel. As deel van 'n navorsingsprojek oor leerderdissipline deur die Potchefstroomse Universiteit vir $\mathrm{CHO}$, het leerders aan Afrikaanse laerskole in die Noordwes-Provinsie aan 'n opstelkompetisie deelgeneem. Die tema van die opstel was "Dissipline by my skool". Die opstelle is ontleed op grond van die inhoud.

Leerders besef die noodsaaklikheid van dissipline, en grond hul mening op praktiese (voorvereiste vir leer) en godsdienstige gronde. Dié wangedrag wat wel voorkom, is van 'n minder ernstige aard (dit wil sê nie kriminele wangedrag nie). Die meeste leerders meen dat die stand van dissipline by hul skole goed is. Ontoereikende ouerleiding word as die vernaamste oorsaak van swak leerderdissipline in skole beskou. 'n Beduidende aantal leerders het geskryf dat bestaande maatreëls om dissipline in skole te handhaaf ondoeltreffend is. Die herinstelling van lyfstraf was die mees algemeen aanbevole alternatief.

Die artikel sluit af met aanbevelings vir verdere navorsing en vir die verbetering van die onderwyspraktyk.

\section{Probleemstelling}

Dat leerderdissipline 'n probleem by Suid-Afrikaanse skole is, blyk duidelik uit onlangs gepubliseerde navorsing (De Wet, 2003a; 2003b; Rossouw, 2003; Mentz et al., 2003; Geyser \& Wolhuter, 2001:94). Vir 'n volledige begrip van die probleem - die oorsake, omvang, uitwerking en korrelate daarvan - is die toereikende daarstel van 'n leerderperspektief noodsaaklik. So 'n perspektief is afwesig in bestaande navorsing oor die onderwerp. Ook in regeringsdokumente soos Alternatives to Corporal Punishment (Department of Education, 2000) - wat sonder enige vermelde inset van leerders saamgestel is - blyk in teenspraak te wees met die demokratisering van die onderwysstelsel, een van die hoekstene van die onderwysbeleid ná 1994 (Wolhuter, 1999:367-370).

'n Leerderperspektief op dissipline is verder vanuit verskeie opvoedkundige oorwegings wenslik. As onderwysers metodes en tegnieke gebruik wat leerders verkies, en ook ' $n$ ingesteldheid toon wat leerders geval, kan dit gestel word dat leerders in sulke gevalle 
meer aandag en tyd aan hul skoolwerk sal bestee (Lewis \& Lovegrove, 1987:173). Die bereiking van die leeruitkomstes sal sodoende ook gefasiliteer word. Die redes wat hiervoor aangevoer word, is dat die bevrediging van leerdervoorkeure op die terrein van klaskamerbeheer aanleiding sal gee tot ' $n$ aangenamer en meer produktiewe klasatmosfeer. 'n Affektiewe gunstige atmosfeer en 'n toereikende verhouding van begrip tussen opvoeder en opvoedeling is immers twee wesentlike elemente van die opvoedingsituasie. Om verdere verdieping aan die gesprek te gee, is besluit om die vraagstuk van 'n leerderperspektief in opvoedingskonteks vanuit 'n reformatoriese denkraamwerk te benader. Dié strategie word hieronder in meer besonderhede verantwoord.

Die doel van dié artikel is gevolglik die bou van 'n leerderperspektief op dissipline in Suid-Afrikaanse skole, en wel vanuit die bestaande kennis oor die onderwerp asook uit 'n reformatoriese perspektief op die leerder, opvoeding en dissipline. Eers word 'n kort prinsipiële besinning oor drie sleutelaspekte van hierdie ondersoek vanuit 'n reformatoriese denkraamwerk gedoen, te wete: die leerder (kindbeeld), opvoeding en dissipline. Hierna volg 'n oorsig van bestaande navorsing oor dissipline in Suid-Afrikaanse skole, asook 'n beoordeling van bevindings vanuit dié denkraamwerk. Daarna volg 'n uiteensetting van die empiriese navorsingsontwerp en die resultate. Laasgenoemde word daarna beoordeel in die lig van bestaande navorsing asook teen die agtergrond van die normatiewe reformatoriese perspektief op die leerder, opvoeding en dissipline. Daarna volg aanbevelings vir verdere navorsing. Die artikel handel spesifiek oor dissipline, en nie oor leerders se gedragsprobleme in die algemeen nie.

\section{2. 'n Reformatoriese perspektief op dissipline}

'n Ontleding en beoordeling van leerders se perspektief op die stand van dissipline in hul skole veronderstel dat daar 'n normatiewe raamwerk vir die beoordeling sal wees. ' $n$ Normatiewe raamwerk is altyd in een of ander stel religieuse (ook ideologiese) oortuigings en aannames of veronderstellings gefundeer. Dit verraai ook die lewensbeskoulike oortuigings waarin dit ingebed is. Vir die doel van dié beoordeling en bespreking is hieroor besin en besluit om die beoordeling vanuit 'n Bybels-gegronde (in dié geval reformatoriese) denkraamwerk te doen.

Dié denkraamwerk is vir die doel van die bespreking doelbewus afgebaken en fokus op drie sleutelaspekte van die tema, te wete: die leerder (kindvisie), opvoeding en dissipline. In die bespreking 
van die drie sleutelaspekte word ook 'n konseptuele raamwerk vir die ondersoek gebou. Vanuit reformatoriese mens- en opvoedingsbeskouing kan die volgende standpunte oor die drie sleutelaspekte van die ondersoek ingeneem word:

\subsection{Die leerder as kind}

Hierdie deel van die ondersoek fokus op kinders as respondente. Die vraag wat by ' $n$ mens opkom, is: Wie en wat is die kind? Die voor die hand liggende antwoord is: Die kind is 'n mens op weg na ontplooiing en ontwikkeling tot volledige volwassenheid. Die kernpunt is dat die kind ' $n$ mens is. Daarom is die reformatoriese mensbeskouing of antropologie volledig op die kind van toepassing (vir so 'n volledige mensbeskouing vanuit reformatoriese perspektief, vergelyk Van der Walt, 1994:153 en verder). Die kind is, soos enige mens, deur God geskape, iemand op soek na selfidentiteit. Die kind is 'n gawe van God aan die ouers en die koms van die kind plaas verantwoordelikhede op die skouers van al die opvoeders. Dit sluit in die ouers en die onderwysers. Die kind is 'n dualiteit van geslagte; dit is 'n holistiese wese; 'n multidimensionele wese; beeld van God; 'n sondaar, medemens; herstelde wese; skepper van kultuur, en vele meer. Die ruimte ontbreek om volledig op dié mensbeeld uit te brei, maar die geleentheid moet tog aangegryp word om aandag te gee aan die kindbeeld. Die kindbeeld berus op die totale mensbeeld, aangesien die mensbeeld die wesenlike van die kindbeeld omvat. Van die kind kan egter eksplisiet die volgende gesê word: die kind is mens wat nog groei na volwassenheid en kindwees is iets unieks - dit is anders as volwassewees. Die kind is iemand wat vir 'n betreklike lang tyd hulpbehoewend en afhanklik van ander bly (soos die ouers en ander opvoeders); nog "onvolledig", 'n potensiële volwassene. Kindwees het egter intrinsieke waarde: die jeugperiode van die mens is onvervangbaar. Die Bybel praat ook van kindwees as 'n eiesoortige wyse van menswees.

\subsection{Die noodsaaklikheid van opvoeding}

Die kern van die periode van kindwees is dat die kind afhanklik is van opvoeding ten einde die status van volledige volwassenheid te kan bereik. Opvoeding is moontlik omdat God die mens gemaak het om nie net op te voed nie, maar om deur opvoeding toegerus te wees vir die volwasse lewe. Opvoeding is ook noodsaaklik, aangesien die kind daarsonder nie tot die status van volwassenheid sou kon groei nie. Die kind sou nie sonder opvoeding gelei, gevorm, toegerus, in staat gestel en gedissiplineer kon word tot roepingsvervulling in diens van God en medemens nie. Die noodsaaklikheid 
van opvoeding is dus dit wat kindwees toevoeg tot menswees, sê Vogelaar en Bregman (1983:97). Deur opvoeding word die kind nie gemaak nie, maar wel verder gevorm. Die aard van die opvoeding word enersyds bepaal deur die samelewingsverband waarbinne dit plaasvind. In dié ondersoek waaroor in hierdie artikel verslag gedoen word, is dit die skool. By geleentheid word ook verslag gedoen oor die ouerhuis. Opvoeding word ook bepaal deur die kind wat in die betrokke geval aan die sorg van opvoeders (onderwysers en ouers) toevertrou is. Die kind kom nie as tabula rasa in die wêreld nie, maar as mens met potensiaal wat deur opvoedende onderwys ontwikkel en ontplooi moet word.

\subsection{Die werklikheid van die sonde}

Volgens Bybelse perspektief is die kind van nature nie geneig om goed of totaal onskuldig voor God en die medemens te wees nie. Om dié rede is daar verskynsels soos wangedrag en dissiplinêre probleme en kan opvoeding nie bloot by die "natuur" van die kind aansluit en die "natuurlike" aanleg van die kind toelaat om te ontplooi nie. $\mathrm{Na}$ die sondeval het die mens nog mens gebly, die kind nog mens, en daarom het opvoeding deur God se genade nog moontlik gebly. Die mens bly, ondanks die sonde, opvoedbaar. Dié opvoedbaarheid verkry verdiepte dimensie as dit raakgesien word dat opvoeding nie bloot gaan oor die toerusting van die kind tot volwassenheid nie, maar dat dit uiteindelik gaan oor toerusting tot diens van God en die naaste (Vogelaar \& Bregman, 1983:98).

Fowler, Van Brummelen en Van Dyk (1993:157 e.v.) vat die opvoedingshandeling in die skool soos volg saam: In die eerste plek kom dit daarop neer dat die kind gelei word op 'n bepaalde weg, nie ' $n$ ander een nie - tot in so 'n stadium dat die kind in staat is om self die weg van diens aan God en medemens te kies. Ten tweede kom dit neer op ontplooiing in dubbele sin: die werklikheid moet vir die kind ontplooi word, en die kind moet ontplooi word om sy of haar taak in die skepping te kan verstaan. Ten derde kom dit neer op instaatstelling of dissipelskap.

\subsection{Dissipline of dissipelskap}

Dissipelskap hou verband met dissipel- of volgelingskap. Om die kind "in staat te stel" (enable), is om die leerder te voorsien van die nodige vaardighede en die bereidheid om op te tree as 'n doeltreffende dissipel (volgeling) van die Here in die hedendaagse wêreld (Fowler et al., 1993:160). Dit is die uiteindelike doel van Bybels-gefundeerde opvoeding (ook opvoedende onderwys in die 
skool). Die leerder word gelei en deur middel van ontplooiing in staat gestel om dissipel te wees. Van Brummelen (1988:2) sê ook dat dit juis die funksie van die skool is om die kind op te voed (te lei en in staat te stel) tot 'n lewe van verantwoordelike dissipelskap in Jesus Christus. (Soos enige kompakte stelling, sit hierdie een vol voetangels, en behoort daar heelwat daarop uitgebrei te word. Die ruimte laat dit egter nie toe nie.) Dissipel- of volgelingskap, die term waarna "dissipline" verwys, kom op die volgende neer. 'n Dissipel, 'n gedissiplineerde persoon, is - vanuit Bybelse perspektief - iemand wat nie slegs die wysheid het om die Woord van God (sy wil, sy wette vir die skepping) te hoor nie, maar ook te verstaan en bereid is om dit te doen. Dit is iemand wat God en die naaste met oorgawe wil en kan dien, onder meer deur die sonde te bestry (Van Dyk, 1997:40 e.v.; Van Dyk, 2000:64 e.v.).

\section{3. 'n Oorsig oor kwantitatiewe bevindinge}

De Wet (2003b) het 'n empiriese ondersoek (vraelyste wat vir hierdie doel gebruik is, het geslote sowel as oop vrae bevat) op 'n gestratifiseerde steekproef van opvoeders en leerders van 40 Vrystaatse skole onderneem, ten einde te bepaal hoe veilig die skole is en wat gedoen kan word om misdaad op skoolpersele te bekamp. Die resultate van die ondersoek het aangetoon dat misdaad soos diefstal (ongeveer die helfte van die opvoeders en ' $n$ kwart van leerders was al slagoffers van diefstal op skoolterreine) algemeen voorkom, maar dat die ernstigste vorm van misdaad (soos verkragting en ernstige aanranding) selde voorkom. Die ondersoek onderskei nie tussen opvoeders en leerders se menings oor moontlike misdaadvoorkomingstrategieë nie.

Van Wyk (2001) het deur middel van fokusgroepgesprekke, waarneming, onderhoude en vraelyste dissiplinepraktyke en persepsies oor dissipline onder opvoeders, leerders en ouers aan stedelike swartskole ondersoek. Die response het die volgende aan die lig gebring:

- Die respondente het gekla oor die ernstige dissiplinêre probleme by skole.

- Opvoeders en ouers beskou lyfstraf steeds as die oplossing vir leerderwangedrag.

- Opvoeders het 'n beperkte kennis van dissiplinestrategieë.

- Eksterne faktore (bv. huislike omstandighede) word oor die algemeen as die vernaamste oorsaak van dissiplinêre probleme beskou. 
- Opvoeders word oor die algemeen as swak rolmodelle vir leerders beskou.

- Dié ondersoek stel egter nie 'n leerderperspektief vir dissiplinêre maatreëls daar nie.

Mabeba en Prinsloo (2000) het met behulp van vraelyste (waar respondente tussen vierpunt-Likertskaal-antwoorde moes kies) die persepsies van leerders, opvoeders en ouers oor dissipline aan hoërskole ondersoek. Die bevindings was soos volg:

- Al drie groepe steun die beginsel van straf as korrektiewe dissiplinêre maatreëls teen oortreders. Met betrekking tot lyfstraf was $49 \%$ van die leerders, $56 \%$ van die ouers en $57 \%$ van die opvoeders ten gunste van lyfstraf.

- Leerders het deelnemende besluitneming oor dissiplinehandhawing voorgestaan, terwyl opvoeders daarteen was. Opvoeders het verkies om hulle eie maatreëls af te dwing.

- Ouers (82\%) en leerders (73\%) was van mening dat die lesvoorbereiding van opvoeders 'n kritieke faktor vir goeie dissiplinebestuur is. Hierteenoor het slegs $44 \%$ van die opvoeders dit as 'n kritiese faktor vir dissiplinebestuur beskou.

- Al drie groepe was dit eens dat dissipline konsekwent toegepas moet word.

Mentz et al. (2003) se empiriese ondersoek aan Afrikaanse skole deur middel van gestruktureerde vraelyste aan skoolhoofde het die volgende aan die lig gebring:

- Van die skoolhoofde het $41 \%$ die stand van dissipline by hulle skole as goed bestempel, $51 \%$ as gemiddeld, terwyl die res (9\%) óf gemeen het dit is swak, óf die vraag nie beantwoord het nie.

- Skoolhoofde openbaar nie 'n gevoel van moedeloosheid oor die stand van dissipline in hul skole nie.

- Skoolhoofde ervaar dat hoewel hulle hulself sedert 1994 in 'n nuwe omgewing bevind waarin ouers en leerders hul regte ken, daar wel die nodige prosedures is om die nuwe omgewing te kan hanteer. Lyfstraf kom egter nog by $10 \%$ van die skole voor.

- Dissiplinêre probleme kom nie in 'n groter mate voor by skole wat multikultureel geword het nie.

- In groter stedelike skole is die voorkoms van dissiplinêre probleme hoër. 
- Dissiplinêre probleme kom minder voor by skole waar ouerbetrokkenheid hoog is.

Rossouw (2003) het deur middel van fokusgroepgesprekke met opvoeders en leerders in die Vrystaat, Wes-Kaap en Noordwesprovinsies bevind dat die mees algemene vorme van leerderwangedrag in skole disrespekvolle gedrag teenoor opvoeders is. In sommige skole kom ernstige probleme (volgehoue afwesigheid, vandalisme, diefstal, daggagebruik, aanranding, eksamenoneerlikheid, pornografie en dobbelary) egter ook voor. Deelnemers het dissiplineprobleme toegeskryf aan die huidige kultuur van menseregte, sowel as aan faktore wat intern en ekstern tot die skool voorkom. Enkele van die interne faktore sluit die volgende in:

- Die manlik-vroulik personeelratio aan skole.

- Leerders het 'n negatiewe invloed op mekaar.

- Klasgroottes.

- Die wetlik voorgeskrewe prosedure om dissiplinêre stappe te doen wat vinnige, doelgerigte optredes onmoontlik maak.

- Die informele aard van uitkomsgebaseerde onderwys.

Die eksterne oorsake sluit die volgende in:

- 'n Gebrek aan dissipline by ouerhuise.

- Leerders se verarmde sosio-ekonomiese gesinsagtergrond van leerders.

- 'n Gebrek aan sorg by ouerhuise.

- 'n Algemene afname in dissipline in die gemeenskap.

Ten opsigte van die hantering van dissipline het deelnemers gemeen die deelname van alle rolspelers is bevorderlik vir goeie dissipline, maar dat lyfstraf, gemeenskapsdiens en 'n stelsel van meriete-demerietepunte nie 'n goeie rekord by hul skole het nie. Rossouw se ondersoek stel ook nie 'n onderskeidende leerderperspektief daar nie.

Maree (2000) het in 'n opname onder leerders bevind dat lyfstraf steeds algemeen by skole in Suid-Afrika voorkom. Morrell (2001) het met behulp van vraelyste aan hoërskoolleerders tot die gevolgtrekking gekom dat lyfstraf aan die histories-blanke-skole verdwyn het, maar steeds taamlik algemeen aan stedelike histories-swartskole voorkom. Verder het alle groepe leerders, met die uitsondering 
van Indiër- en blanke vroulike leerders, steeds lyfstraf as die mees algemene straf beskou. Morrell verbind die oortuiging dat lyfstraf noodsaaklik is vir ordelike opvoeding aan die feit dat dit nog algemeen in ouerhuise voorkom.

Wanneer daar tot 'n evaluering van die stand van wetenskaplike literatuur oor dissipline aan Suid-Afrikaanse skole oorgegaan word, moet dit ten aanvang gestel word dat al bovermelde studies waardevolle en tydige inligting daarstel. Tog bestaan die volgende drie stelle leemtes:

- 'n Duidelik onderskeidende leerderperspektief ontbreek.

- 'n Oorveralgemeende beeld word geskilder. Die Suid-Afrikaanse skoleversameling is 'n ryk geskakeerde mosaïek. Die histories swart- Kleurling-, Indiër- en blanke skole (en binne die blanke kategorie weer die histories-Afrikaanse en -Engelsmediumskole) het elk hul eie etos. Verder is daar nog die verskille tussen stad en platteland, groot en klein skole, en hoër- en laerskole. Die meeste navorsing poog om bo-oor die verskille 'n veralgemeende beeld te skep. Boonop is dit 'n beeld wat ook die verskillende perspektiewe van die verskillende rolspelers (leerders, opvoeders, ouers) negeer. Ten einde 'n akkurate beeld van dissipline in Suid-Afrikaanse skole met al hulle skakerings te rekonstrueer, moet die bestaande navorsing aangevul word met studies vanuit meer homogene navorsingsterreine.

- Metodologiese tekortkomings. Al die bestaande studies het óf vraelyste, óf fokusgroepsessies, óf enkele gevalle-onderhoude gebruik. Dié vraelyste, fokusgroepbesprekings en onderhoude was meestal gestruktureerd of semigestruktureerd.

- Vanuit die reformatoriese perspektief op die leerder as kind, opvoeding en dissipline as dissipelskap van Jesus Christus soos uiteengesit in punt 2 hierbo, toon dié studies voorts nie die nodige verdiepte insig nie. Om maar enkele sake te noem waarop die Bybels-gefundeerde benadering verdiepte perspektief verskaf: misdaad is inderdaad ' $n$ voorbeeld van 'n gebrek aan naasteliefde en 'n weiering om die voorbeeld van Jesus Christus na te volg, "ernstige dissiplinêre probleme" dui op 'n gebrek aan 'n begeerte om in die spore van Christus te loop. "Opvoeders as swak rolmodelle" dui daarop dat hulle nie oor die nodige insig beskik om die leerders te lei, te ontplooi, in staat te stel, en van hulle ware volgelinge te maak op die weg wat God in sy Woord aandui nie. So kan die voorbeelde uit die oorsig hierbo vermenigvuldig word. Daar moet toegegee word dat dit moeilik is 
om dié reformatoriese siening op die kind, opvoeding en dissipline uit te leef in die sekulêre skole waarin onderwysers en leerders hulle tans in Suid-Afrika bevind. Van Dyk (1997:5) definieer sekularisme soos volg: "Secularism is wherever I ignore or set aside the will of God." Dit is wat skynbaar oor die algemeen in die huidige samelewing gebeur (vgl. Middleton \& Walsh, 1995: 25).

\section{Kwalitatiewe metodologie}

As deel van 'n navorsingsprojek oor leerderdissipline aan die Potchefstroomse Universiteit vir $\mathrm{CHO}$ is leerders aan Afrikaanse laerskole gevra om aan 'n opstelkompetisie deel te neem. Die tema van die opstel wat 400-600 woorde lank moes wees, was "Dissipline by my skool". Die volgende riglyne is aan leerders verskaf:

- Werk 'n gebrek aan dissipline in die klaskamer nadelig in op jou skoolwerk?

- Hoe ervaar jy die wyse waarop dissipline in jou skool gehandhaaf word?

- Word dissiplinêre maatreëls konsekwent toegepas?

- Dink jy die metodes om dissipline in jou skool te handhaaf, is doeltreffend?

- Wat sal jy wil verander?

- Op watter manier hinder sommige leerders die onderwyser in sy taak?

Die uitnodiging om deel te neem, is gepubliseer in die streekkoerant Pylvak. Pylvak word uitgegee deur Advert Square en Spartan Kommunikasie in diens van die jeug en hul ouers wat in die Noordwes-Provinsie woon. Dit word gratis versprei na skole in die Potchefstroom-, Klerksdorp-, Orkney-, Stilfontein- en Ventersdorpdistrikte. Die uitnodiging is geplaas saam met die koerant se beriggewing oor die Potchefstroomse Universiteit se navorsingsprojek oor leerderdissipline.

Dit is 'n reël in wetenskaplike navorsing dat vanaf die eenvoudige na die komplekse beweeg word. Navorsing het getoon dat laerskole met minder sowel as minder ernstige dissiplinêre probleme te kampe het as hoërskole (National Center for Education Statistics, 2002; Fields, 2000). Gevolglik bied dié navorsing 'n leerderperspektief op leerders aan Afrikaanse laerskole ten opsigte van dissipline. Die plan is om die navorsing later uit te brei na ander 
kategorieë skole waar leerderdissipline na alle waarskynlikheid 'n groter en 'n meer komplekse probleem is, byvoorbeeld hoërskole, Engels-medium histories-blanke skole met hul meer heterogene bevolkingsamestelling en histories-swart skole, waar die dissiplineprobleem ineengestrengel is met ander probleme. By laasgenoemde is daar die probleem dat baie leerders uit arm huisgesinne kom en ook die feit dat dié skole 'n geskiedenis het om as 'n politieke speelveld misbruik te word.

Terwyl die metode van navorsing nie die samehang tussen dissiplinêre probleme en faktore soos die sosio-ekonomiese oorsprong van leerders kan peil nie, is sodanige samehange reeds ondersoek deur navorsing wat van kwantitatiewe metodes gebruik maak (Bear, 1998).

Die respondente tot die opstelkompetisie het grootliks uit Graad 6en 7-leerders bestaan. Op dié wyse geniet baie van die leemtes in die voorgemelde navorsing tog aandag:

- 'n eksklusiewe leerderperspektief word daargestel;

- die studieterrein is meer homogeen wat leerderfase en skooltipe betref;

- leerders het meer vryheid tot ongebonde meningsuiting as in die geval van die vraelyste, groepbesprekings en onderhoude van die vorige studies.

Die skole is almal enkelmedium Afrikaanse skole, geleë in histories blanke woonbuurte. Die skrywers meen daarom dat dit geregverdig is om die aanname te maak dat al, of feitlik al die respondente, blanke leerders was.

Die navorsingsmetode wat by die verwerking van die ingesamelde inligting gebruik is, is inhoudsontleding (content analysis). Inhoudsontleding kan omskryf word as 'n gedetailleerde en gesistematiseerde ondersoek na die inhoud van 'n bepaalde hoeveelheid gegewens ten einde patrone te identifiseer (Leedy \& Ormrod, 2001: 155). As navorsingsmetode sluit dit sowel die kwantitatiewe (insluitende frekwensiebepaling) as kwalitatiewe metodes in. Dit word tipies uitgevoer op vorms van menslike kommunikasie, insluitende boeke, koerante, films, televisie, kuns, musiek, videobande van menslike kommunikasie en transkripsies van gesprekke (Sarantakos, 1998:279, 281; Leedy \& Ormrod, 2001:155). Leedy en Ormrod (2001:156) beskryf die stappe van inhoudsontleding soos volg: 
(i) Die navorser selekteer die spesifieke materiaal wat bestudeer moet word.

(ii) Die navorser besluit op die eienskappe wat bestudeer moet word.

(iii) Die eienskappe word in klein, hanteerbare segmente verdeel.

(iv) Die materiaal word met betrekking tot die eienskappe van stap (ii) en die kategorieë van stap (iii) ondersoek.

Sarantakos (1998:286) noem as een van die sterk punte van inhoudsontleding dat dit onopdringend is (unobtrusive) en sodoende nie die respondent beïnvloed nie.

\section{Kwalitatiewe resultate}

Vier en sestig Graad 6- en 7-leerders het deelgeneem. Die leerders wat hul skooladresse by hul opstelle geskryf het (sommige het hulle huisadresse bygeskryf) het vanaf vyf skole gekom (die koerant word na veertien Afrikaanse laerskole versprei). Kwalitatiewe navorsing verskil van kwantitatiewe navorsing in die opsig dat waar kwantitatiewe navorsing met verteenwoordigende steekproewe van groot omvang werk, kwalitatiewe navorsing tipies met klein steekproewe werk (Leedy \& Ormrod, 2001:102). Die verskil kan in verband gebring word met die onderskeie doelstellings van kwantitatiewe en kwalitatiewe navorsing, soos uiteengesit deur Leedy en Ormrod (2001:102). Die doel van kwantitatiewe navorsing is om te voorspel en 'n teorie te toets, terwyl die doelstellings van kwalitatiewe navorsing is om te verduidelik en te interpreteer. In die geval van hierdie ondersoek gaan dit om kwalitatiewe navorsing, wat gekenmerk word deur die feit dat dit 'n klein getal gevalle is wat diepgaande ondersoek word om die verskynsel te begryp, eerder as 'n groot verteenwoordigende steekproef, met die uiteindelike oogmerk om die resultate na 'n nog groter populasie te veralgemeen. Die skrywers meen tog dat die resultate van die studie veralgemeen kan word na die meeste Afrikaanse laerskole in Suid-Afrika, waar middelklas Afrikaanssprekende leerders die meerderheid van die leerderkorps vorm.

Die volgende kategorieë is gebruik om die opstelle te ontleed:

- Wat leerders onder dissipline verstaan

- Die stand van dissipline by hul skole

- Die uitwerking wat die huidige stand van dissipline op hulle het

- Oorsake/korrelate van (goeie en swak) dissipline by hul skole 
- Die hantering van dissipline by hul skole

- Die mate waarin die respondente daarin slaag om iets weer te gee van die Bybelse (in hierdie geval reformatoriese) perspektief op die kind, opvoeding en dissipline

Die inligting wat verkry is op grond van die inhoudsontleding is laastens geïntegreer en vergelyk met inligting beskikbaar in ander bestaande navorsing, soos aangedui in die literatuuroorsig hierbo. Die doel van sodanige vergelyking en integrasie is tweeledig. Enersyds bied die leerderperspektief ' $n$ aanvulling, selfs 'n korrektief vir die bestaande navorsingsresultate, wat grotendeels op persepsies van skoolhoofde en onderwysers gebou is. Andersyds kan die perspektiewe van hoofde en onderwysers dien as instrument ter kontrolering van die feit dat ouers en onderwysers se invloed, asook die pryse wat vir die beste opstelle uitgeloof is, leerders moontlik kon beweeg het om "mooi" opstelle te skryf wat hul skole in 'n gunstige lig stel.

\subsection{Leerderkonseptualisering van dissipline}

Dertien van die leerders wat die begrip dissipline omskryf het, het dit verbind met die begrip gehoorsaamheid, tien met die idee om reëls na te kom, ses met ordelike gedrag, vyf met goeie maniere, drie elk met die beginsel van selfdissipline en 'n houding van respek teenoor mense in gesagsposisies, twee met respek teenoor onderwysers, en een elk met 'n goeie voorbeeld, netheid, bedagsaamheid, werk goed doen, en die beginsel van straf. Hoewel al dié respondente blyke gegee het dat hulle iets verstaan van die feit dat dissipline te doen het met volgelingskap, het nie een van hulle uitdruklik te kenne gegee dat hulle dit vereenselwig met die gedagte dat dit daarop dui om die voorbeeld van Jesus Christus na te volg nie. Hierdie toedrag van sake dui daarop dat dissipline in hierdie sin nie deur die ouerhuise of skole by die leerders tuisgebring word nie.

\subsection{Die noodsaak van dissipline}

Twee en vyftig leerders het hulle duidelik vir die beginsel en noodsaak van dissipline uitgespreek. Geen leerder het hom/haarself teen die handhawing van dissipline uitgespreek nie.

Leerders het die noodsaaklikheid vir dissipline soos volg begrond:

- Twee en twintig het geskryf dissipline in die skool is noodsaaklik vir hulle om te kan leer.

- Nege het dit vanuit religieuse gronde begrond. 
- Ses het geskryf dat reëls orde skep.

- Ses het geskryf dat reëls 'n gevoel van veiligheid en sekerheid skep.

- Vier het geskryf dissipline is nodig vir die doeltreffende funksionering van die skool.

- Vier het geskryf dat 'n volwassene volgens die reëls van die samelewing leef.

- Drie het geskryf dat dissipline noodsaaklik is vir 'n suksesvolle lewe.

Al die response was bemoedigend vanuit 'n reformatoriese perspektief op die kind, opvoeding en dissipline. Veral die begronding vanuit godsdienstige oorwegings was verblydend. 'n Mens sou egter wou sien dat die leerders almal te kenne gegee het dat hulle besef dat sonde wat in die skepping ingekom het, opvoeding vir hulle noodsaaklik gemaak het, en daarmee saam ook dissipline. Slegs deur in die voetspore van Jesus Christus in hierdie sondegebroke wêreld te loop, kan 'n mens relatief ongeskonde daar deurgaan.

\subsection{Die stand van dissipline}

Agtien leerders het 'n evaluering oor die stand van dissipline by hul skole uitgespreek, van wie elf gemeen het dit is goed, terwyl ses geskryf het dit is swak, en een gemeen het dit is normaal.

Leerders het oor die volgende vorms van wangedrag gekla:

- Negentien het gekla oor die ontwrigtende gedrag van medeleerders,

- vier oor ongemanierdheid,

- twee oor pligsversuim en

- een elk oor geraas, skeltaal, bakleiery, ongehoorsaamheid, laatkommery, afwesigheid sonder rede en uittartende gedrag teenoor onderwysers.

Oor die voorkoms van ongedissiplineerde leerders, het ses geskryf sodanige leerders maak ' $n$ klein groepie van die totale leerdertal uit. 'n Verdere vyf het dit gekwantifiseer - een leerder het geskryf die helfte van die klas, een $20 \%$, een $15 \%$ en een het geskryf een of twee per klas maak hulle skuldig aan wangedrag.

Al die respondente het hoofsaaklik op die voorkoms van die probleme gedui, en veral op die simptome van swak dissipline 
gekonsentreer. Nie een het dit werklik geëvalueer vanuit die verdiepte perspektief op die kind, opvoeding en dissipline as volgelingskap van Jesus Christus nie. Daar was nie veel blyke dat die respondente werklik verstaan het wat "swak dissipline" of "normale dissipline" beteken nie. Dié toedrag van sake dui daarop dat die verdiepte perspektief sowel in die betrokke ouerhuise as in die skole nie onder die leerders se aandag gebring word nie.

\subsection{Die effek van die huidige stand van leerderdissipline}

In die lig daarvan dat die meeste leerders wat hulle uitgespreek het oor die stand van dissipline by hulle skole 'n positiewe oordeel gefel het en dat dié wat gekla het, oor betreklike geringe vorms van wangedrag gekla het, was dit nie verrassend dat slegs elf leerders geskryf het oor die negatiewe uitwerking wat die stand van dissipline op hulle het nie. Dié elf het die volgende geskryf:

- Ses het gekla dat hulle nie hul skoolwerk na behore kan doen nie,

- vier het gekla oor die uitwerking van swak dissipline op stygende spanningsvlakke en gevolglike kortgebondenheid van onderwysers en

- een het geskryf die geraas is te veel om te verduur.

\subsection{Korrelate vir die huidige dissiplinêre klimaat}

Met betrekking tot die oorsake van swak dissipline het die leerders soos volg geskryf:

- Nege het geskryf dat swak leerderdissipline sy oorsprong het in 'n gebrek aan dissipline by die ouerhuise,

- een het dit toegeskryf aan die swak voorbeeld wat ouers stel,

- drie het swak leerderdissipline toegeskryf aan die feit dat onderwysers wetlik magteloos is om op te tree teen leerders wat hulle wangedra, en dat leerders binne die huidige kultuur van menseregte te veel beskerming geniet,

- een het geskryf dat onderwysers te familiêr met leerders is en

- een het geskryf dat onderwysers lesse vervelig aanbied.

Dit is interessant om te merk hoe na die respondente daaraan gekom het om die werklike oorsake van swak of ontoereikende dissipline raak te sien. Hulle kon egter nie deurdring tot die diepste oorsaak nie, naamlik dat die sonde die mens verhoed om Jesus 
Christus met oorgawe te volg. Opvoeding kan in hierdie sondige bedeling ook nie plaasvind soos dit behoort te gebeur nie.

Oor die grondtone van goeie dissipline het die leerders soos volg geskryf:

- Een het geskryf dat die waarde van 'n goeie voorbeeld, gebaseer op Christelike beginsels van groot waarde is,

- een het geskryf dat skool- en klaskamerreëls konsekwent toegepas moet word,

- een het geskryf dat dié reëls duidelik moet wees en aan almal bekend gemaak moet word,

- twee het geskryf oor die rol wat die skoolhoof speel - dat hy/sy 'n goeie voorbeeld moet stel, toeganklik moet wees, en goeie verhoudinge met leerders en onderwysers moet handhaaf,

- een het geskryf oor die waarde van goeie onderwysers en

- een het geskryf dat leerders wat sport beoefen, oor die algemeen goed gedissiplineerd is.

Die eerste respons wat hierbo aangegee is, was bemoedigend in die lig van die normatiewe beoordelingsraamwerk. Die ander het egter nie tot die kern van goeie dissipline deurgedring nie.

\subsection{Dissiplinêre maatreëls}

Uit die opstelle blyk dit dat die skole die stelsel van 'n kombinasie van 'n anekdotiese verslag van elke leerder en/of 'n strafboek en/of punte-demerietestelsel en 'n detensieklas vir oortreders gebruik. Dit word dan in die geval van volgehoue oortreders opgevolg met ' $n$ gesprekvoering met die ouers. Veertien leerders het geskryf dat die stelsel ondoeltreffend is (teenoor nege wat geskryf het dit is effektief). Van dié het twee geskryf dat leerders vir die stelsel lag en dink dit is 'n grap. Een het geskryf dat 'n detensieklas vir 'n onderwyser 'n groter straf is as vir 'n leerder.

Vyf en twintig leerders het gevra vir die herinstelling van lyfstraf en meen dit sal meer doeltreffend wees (onder die vyf en twintig het drie verwys na die feit dat lyfstraf nog in ouerhuise toegepas word). Twee leerders het hulle uitgespreek teen lyfstraf en geskryf dat hulle die gevolge daarvan sien in hul ouers se kortgebondenheid.

Agt leerders het geskryf dat die oorsprong vir goeie dissipline en opvoeding in die ouerhuis gesetel is. 
Laastens het ' $n$ aantal leerders vir 'n positiewe benadering gevra:

- Een leerder het gemeen 'n stelsel van merietepunte (vir goeie gedrag) moet ingestel word.

- Een leerder het geskryf dat leerders meer verantwoordelikhede gegee moet word (beurte om klasleiers te wees, patrolliediens te verrig, ens.).

- Een leerder het geskryf dat ouers meer by die skool betrek moet word.

- Twee leerders het gevra vir motivering, 'n fokus op die positiewe, en opvoeding wat fokus op karaktervorming en die bou aan 'n positiewe selfbeeld.

Uit dié oorsig is dit duidelik dat die meeste leerders met 'n konsep van "dissipline" werk wat eerder dui op straf/vergelding vir en regstellende aksie van afwykende gedrag. Dit is egter nie wat dissipline ten diepste beteken nie. Ander leerders het 'n dieper insig getoon. Hulle het ingesien dat die oorsprong van dissipline as volgelingskap deel van die opvoeder se taak is (in die ouerhuis, byvoorbeeld) en dat 'n mens dissipline in 'n positiewe lig moet benader. Hul response het daarop gedui dat hulle verstaan dat dissipline te doen het met die feit dat leerders in staat gestel word om die voorbeeld van Jesus Christus na te volg. 'n Mens let in dié verband op die gebruik van die woorde soos "meriete", "goeie gedrag", "meer verantwoordelikheid", "leiers te wees", "diens te verrig", "motivering", "fokus op die positiewe", "opvoeding tot karaktervorming" en "positiewe selfbeeld". Al dié frases dui daarop dat diegene wat bogenoemde gebruik het, inderdaad iets van ware dissipline/dissipelskap verstaan.

\section{Gevolgtrekking}

In die gevolgtrekking word gepoog om die volgende viertal aangeleenthede te dek: 'n samevatting van die inhoudsontleding, integrering van die resultate by die bestaande korpus wetenskaplike literatuur, aanbevelings vir praktykverbetering en aanbevelings vir verdere navorsing.

Die leerders besef die noodsaak van dissipline wat hulle begrond vanuit pragmatiese (noodsaaklik ten einde hulle in staat te stel om te leer) en religieus-lewensopvatlike gronde. Die meeste leerders meen die stand van dissipline by hul skole is goed. Wangedrag wat wel by die studiepopulasie voorkom, is van 'n minder ernstige aard (erg ontwrigtende gedrag en kriminele gedrag kom nie voor nie). Leerders beskou die ouerbegeleidingsfaktor as die grootste oorsaak 
van swak dissipline onder leerders. 'n Beduidende aantal leerders meen die huidige dissiplinêre maatreëls is ondoeltreffend.

Hierdie ondersoek het aangetoon dat daar in die ouerhuis en skool 'n mate van 'n leemte bestaan met betrekking tot die wyse waarop die betrokke leerders (respondente in die ondersoek) tot die insig gebring word dat hulle ook mense is in die ware sin van die woord, maar kindermense is wat nog gelei en in staat gestel (moet) word om nie slegs die woord (wil, wette) van God te gehoorsaam nie, maar dit ook te verstaan en te doen. Hulle is ook nog nie deur hul opvoedende onderwys in ouerhuis en skool gebring tot die dieper besef van wat dissipline in der waarheid is nie. Dit is naamlik om God en naaste met oorgawe te dien, die sonde en die geweld daarvan in die skepping te bestry (dissipline-probleme uit die weg te ruim) en om in die voetspore van Jesus Christus te loop. Wie byvoorbeeld Christus se oproep navolg om God en die naaste met totale oorgawe te dien, is ' $n$ ware dissipel van Hom. Dié verdiepte insigte het skynbaar nog nie by hierdie groepe respondente deurgedring nie.

Wanneer gepoog word om dié resultate by dié navorsing wat onderneem is (soos uiteengesit in die literatuuroorsig) te integreer, moet dit ten aanvang gestel word dat die terrein van dié ondersoek nie presies met enige van die ander ooreenkom nie. Dit kom slegs met dié van Mentz et al. (2003) ooreen en ook net naastenby. Die studie van Mentz et al. betrek 'n veel groter hoeveelheid Afrikaanse skole. Die navorsingspan waarvan die skrywers deel is, is tans besig om die oefening (leerderopstelle oor dissipline) in ander kategorieë skole (hoërskole, histories blanke Engelsmediumskole, en histories swart-skole) te herhaal. Wat Afrikaanse skole betref, stem Mentz et al. se resultate van hoofde se persepsies in die volgende opsigte ooreen met dié van hierdie studie. Dit is naamlik dat die stand van dissipline by Afrikaanse skole goed is; dat swak dissipline tot nieernstige vorms van wangedrag beperk is, en dat ouers 'n beduidende faktor is in leerderdissipline. Die hoofde se siening dat doeltreffende prosedures ingestel is om dissiplineprobleme te hanteer, word egter nie deur die leerders gedeel nie. Die feit dat in hierdie opsig 'n duidelike meningsverskil met hoofde bestaan, is vir die skrywers 'n aanduiding dat onderwysers en hoofde die leerders nie beïnvloed het in die skryf van die opstelle nie.

Slegs 'n beligting vanuit die perspektief van die ander rolspelers (onderwysers, ouers) aangevul met ander navorsingsmetodes soos observasie en indringende onderhoude sal 'n volledige beeld van die dissipline-aangeleentheid by die skole skep. Indien sodanige 
navorsing die resultate van hierdie ondersoek bevestig, sal die twee aangewese stappe die volgende wees: ouerbegeleiding en die instel van doeltreffende maatreëls om dissipline te verseker. Te oordeel aan leerders se opvatting oor wat dissipline beteken en oor hoe dissipline gehanteer word, is daar 'n noodsaak vir opvoedkundiges om ouers sowel as leerders en opvoeders voor te lig en te begelei met die eksperimentering van metodes soos dié van Lovegrove et al. en die nuwe leer van positiewe dissipline. Dit is interessant om in gedagte te hou dat geen leerder melding gemaak het van enige positiewe maatreël/benadering by skole nie en hul opvatting dat lyfstraf die doeltreffendste metode is om dissipline te bewerkstellig. Wanneer die uitkomste van sulke proefnemings weer aan navorsing onderwerp word, kan dit die basis vorm van voorligting en hulpverlening aan ander kategorieë skole waar, te oordeel aan die literatuur (soos hierbo bespreek), die dissiplineprobleme veel ernstiger is.

\section{Bibliografie}

BEAR, G. G. 1998. School discipline in the United States: Prevention, correction and long term social development. School Psychology Review, 27(1):1419. [In EBSCOHost: Academic Search Elite, Full display: http://www.sa.ebsco.com] [Datum van toegang: 17 April 2002].

DEPARTMENT OF EDUCATION. 2000. Alternatives to corporal punishment. Pretoria : Department of Education.

DE WET, C. 2003a. Misdaad in die Suid-Afrikaanse onderwys soos weerspieël in die gedrukte media. South African Journal of Education, 23(2):113-121.

DE WET, C. 2003b. Skoolveiligheid en misdaadbekamping: die sieninge van 'n groep Vrystaatse leerders en opvoeders. South African Journal of Education, 23(2):85-93.

FIELDS, B.A. 2000. School discipline: Is there a crisis in our schools? Australian Journal of Social Issues, 35(1):73-87 [In EBSCOHost: Academic Search Elite, Full display: http://www.sa.ebsco.com] [Datum van toegang: 17 April 2002].

FOWLER, S., VAN BRUMMELEN, H.W. \& VAN DYK, J. 1993. Christian schooling: Education for freedom. Potchefstroom : IRS.

GEYSER, H.C. \& WOLHUTER, C.C. 2001. Careerpaths of education graduates and its implications for higher education. South African Journal of Higher Education, 15(2):93-97.

LEEDY, P.D. \& ORMROD, J.E. 2001. Practical research: planning and design. Upper Saddle River, New Jersey : Prentice Hall.

LEWIS, R. \& LOVEGROVE, M.N. 1987. The teacher as disciplinarian. How do students feel? Australian Journal of Education, 32(2):173-186.

LOVEGROVE, M., LEWIS, R. \& BURMAN, E. 1989. Classroom discipline. (In Langford, P., ed. Educational Psycology. Melbournbe : Longman. p. 255281.) 
MABEBA, M.Z. \& PRINSLOO, E. 2000. Perceptions of discipline and ensuring disciplinary problems in secondary education. South African Journal of Higher Education, 20(1):34-41.

MAREE, K. 2000. What cannot be endured must be cured: untying the Gordian knot of violence in South African schools. Acta Criminologia,13(2):1-12.

MENTZ, P.J., STEYN, S.C. \& WOLHUTER, C.C. 2003. Die voorkoms van dissiplinêre probleme in Afrikaanse skole. Voorfinale manuskrip. Potchefstroom : Fakulteit Opvoedingswetenskappe.

MIDDLETON, J.R. \& WALSH, B.J. 1995. Truth is stranger than it used to be. Downer's Grove : InterVarsity.

MORRELL, R. 2001. Corporal punishment in South African schools: a neglected exploration for its persistence. South African Journal of Education, 21(4):292-299.

NATIONAL CENTER FOR EDUCATIONAL STATISTICS (United States of America). 2002. Violence and discipline problems in U.S. Public Schools:1996-97. [In EBSCOHost: Academic Search Elite, Full display: http://www.sa.ebsco.com] [Datum van toegang: 23 April 2002].

ROSSOUW, J.P. 2003. Learner discipline in South African public schools - a qualitative study. Voorfinale manuskrip. Potchefstroom: Fakulteit Opvoedingswetenskappe.

SARANTAKOS, S. 1998. Social research. South Yawa : MacMillan.

VAN BRUMMELEN, H. 1988. Walking with God in the classroom. Burlington : Welch.

VAN DER WALT, B.J. 1994. The liberating message. Potchefstroom : IRS.

VAN DYK, J. 1997. Letters to Lisa. Conversations with a Christian teacher. Sioux Center : Dordt College Press.

VAN DYK, J. 2000. The craft of Christian teaching. Sioux Center: Dordt College Press.

VAN WYK, N. 2001. Perceptions and practices of discipline in black schools in South Africa. South African Journal of Education, 21(3):195-201.

VOGELAAR, D. \& BREGMAN, C. 1983. Mens- en kindbeeld in bijbelsreformatorische zin. Hendrik Ido Ambacht : Begeleidingscentrum Gereformeerd Schoolonderwijs.

WOLHUTER, C.C. 1999. Sociaal-wetenschappelijke literatuur over onderwÿs in Zuid-Afrika: van verzuiling tot eensgezindheid vanuit verscheidenheid. Pedagogische Studiën (Nederland), 76(6):361-370.

\section{Kernbegrippe:}

leerderdissipline leerderperspektief opvoedkunde

\section{Key concepts:}

\section{Education}

learner discipline learner perspective 